\title{
GROUNDWATER VULNERABILITY ASSESSMENT TO SEAWATER INTRUSION THROUGH GIS - BASED GALDIT METHOD. CASE STUDY: ATALANTI COASTAL AQUIFER, CENTRAL GREECE
}

\author{
Lappas I. ${ }^{1}$, Kallioras A. ${ }^{2}$, Pliakas F. ${ }^{3}$ and Rondogianni Th. ${ }^{2}$ \\ ${ }^{1}$ Institute of Geology and Mineral Exploration, Department of Hydrogeology, ${ }^{\text {st }}$ Spirou Loui St., \\ Olympic Village, 13677 Acharnae, Athens, Greece \\ ${ }^{2}$ National Technical University of Athens, School of Mining and Metallurgical Engineering, \\ Laboratory of Engineering Geology and Hydrogeology \\ ${ }^{3}$ Democritus University of Thrace, Department of Civil Engineering, 67100, Xanthi, Greece
}

\begin{abstract}
Groundwater resources assessment has resulted in development of models that help identify the vulnerable zones. This paper presents a GIS-based hydrogeological index, named GALDIT, aiming at the assessment of aquifer vulnerability to seawater intrusion in Atalanti coastal aquifer, Central-Eastern Greece. The above acronym is formed from the most important factors controlling seawater intrusion, that is, four intrinsic hydrogeological parameters, one spatial parameter and one boundary parameter including Groundwater occurrence (aquifer type), Aquifer hydraulic conductivity, depth to groundwater Level above the sea (hydraulic head), Distance from the shore, Impact of seawater intrusion and aquifer's Thickness. These factors include the basic requirements needed to assess the general salinization potential of each hydrogeological setting. Each parameter is evaluated with respect to the other to determine the relative importance of each factor. GALDIT model is described to assess and quantify the significance of vulnerability to seawater intrusion due to excessive groundwater withdrawals. Different thematic maps are prepared for seawater intrusion indicators and overlaid to develop the final vulnerability map. The derived map can be used as a tool for coastal groundwater resources management and areas' determination of potential saltwater intrusion since the result of GALDIT index is classified based on vulnerability rate.

Keywords: coastal aquifer vulnerability, index and overlay method, salinization, controlling factors, groundwater contamination.
\end{abstract}

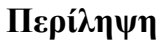

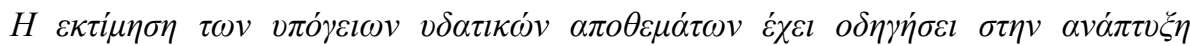

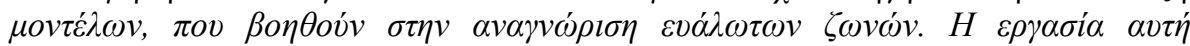

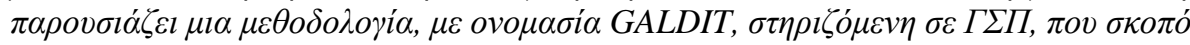

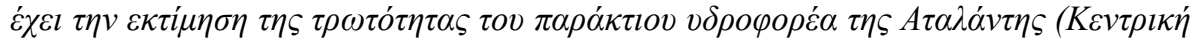

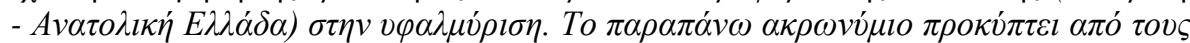

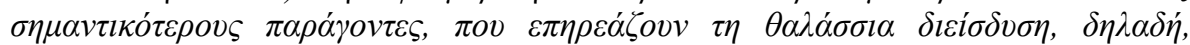

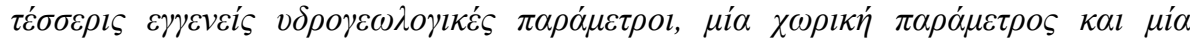

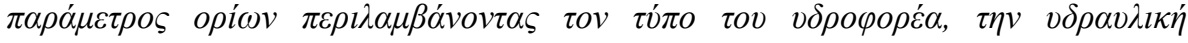




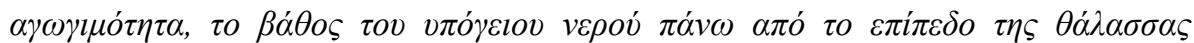

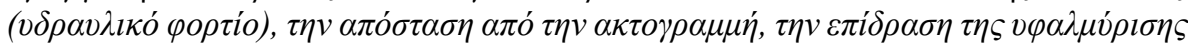

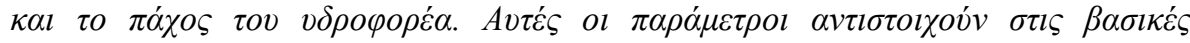

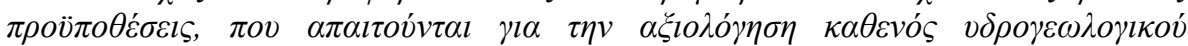

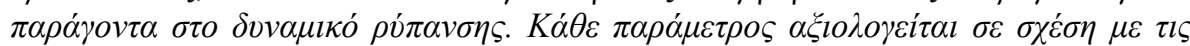

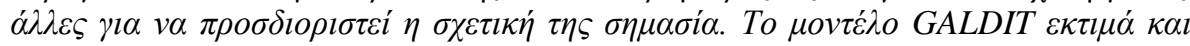

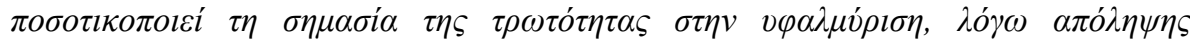

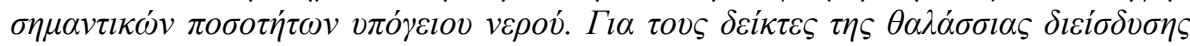

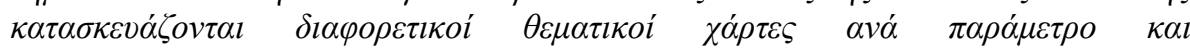

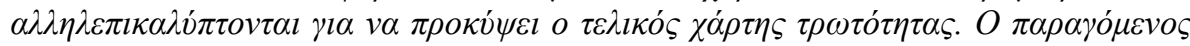

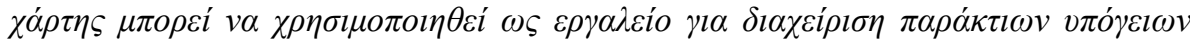

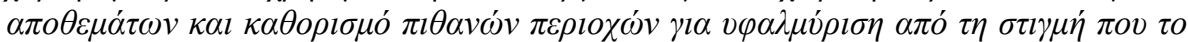

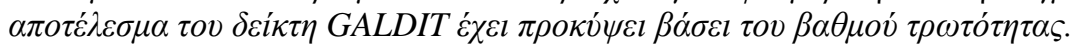

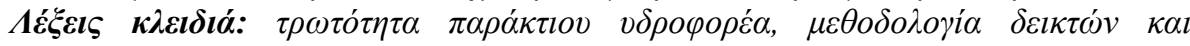

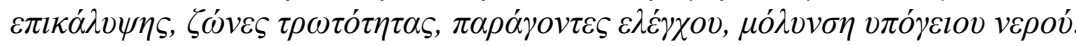

\section{Introduction}

Environmental problems especially in the coastal areas have intensified over the last decades because of rapid industrialization and excessive use of the natural resources while facing several hy drogeological problems due to overexploitation of groundwater resources coupled with uncontrolle $\mathrm{d}$ water consumption. Additionally, groundwater withdrawals in excess of safe yields and reduced recharges to groundwater due to rapid changes of land use patterns along the coast have increased the incidence of seawater intrusion into coastal aquifers. Saltwater intrusion is a very important con cern issue in coastal zones, especially in the low-laying areas which are more prone to seawater intrusion problems, as is the case of the study area. Assessing the coastal aquifer vulnerability to se awater intrusion is a very important step for the future management of any coastal aquifer. Groundwater vulnerability to sea water intrusion may be defined as the sensitivity of groundwater quality to pumping or sea level rise determined by the aquifer's intrinsic characteristics. Population growth dynamics, agricultural, industrial and domestic water demands are responsible for exploitat ion the available groundwater with decreasing recharge areas. Coastal aquifers in addition to land $\mathrm{c}$ ontamination are vulnerable to salinization phenomena. Moreover, groundwater extraction increase s saltwater intrusion by disturbing the balance of saltwater - freshwater interface. In the present study the methodology of GIS-based GALDIT index has been applied to characterize the coastal hydrogeological settings and obtain a potentially vulnerability distribution map of Atalanti coastal aquifer involving measurable weighted and rated parameters (numerical ranking system). Once GA LDIT index is computed, it is possible to identify regions susceptible to seawater intrusion and identify saltwater intruded areas using indicators of salinization such as Revelle coefficient. Finally , field data from two different periods are used (2004-2008 and 2014-2015) in order to analyze the sensitivity of certain aquifer's hydrogeological parameters with respect to seawater intrusion.

\section{Study Area}

\subsection{Site Location - Geomorphology - Drainage Network}

The Water District of Eastern - Central Greece administratively belongs to the Eastern Greece Pref ecture, with longitude between $21^{\circ} 49^{\prime}-24^{0} 37^{\prime}$ and latitude between $37^{0} 55^{\prime}-39^{0} 19^{\prime}$. The Water Di strict's total area is approximately $12.23 \times 10^{3} \mathrm{~km}^{2}$, where the mainland is bounded by the mountain s of Orthris, Timphristos, Giona - Parnassos and Parnitha from the North, Northwest, Southwest an $\mathrm{d}$ Southeast respectively. The rest of the area is surrounded by sea. Particularly, the study area is located at Eastern Central Greece at Lokrida province of Fthiotida Prefecture. Atalanti basin area (app. $250 \mathrm{~km}^{2}$ ) consists of parts with relatively mild slopes in valley where alluvial deposits are met and areas with steep slopes in rocky formations (Figure 1, left). The elevation range between the 
lowest (sea level) and the highest point is app. $660 \mathrm{~m}$. The study area is surrounded by higher or lower mountains and hilly areas (Palivos, 2001; Pavlidou, 2010). The water's erosive - weathering ability combined with the regional geology and tectonics (Figure 1, right) are the main factors which form the current geomorphological conditions.
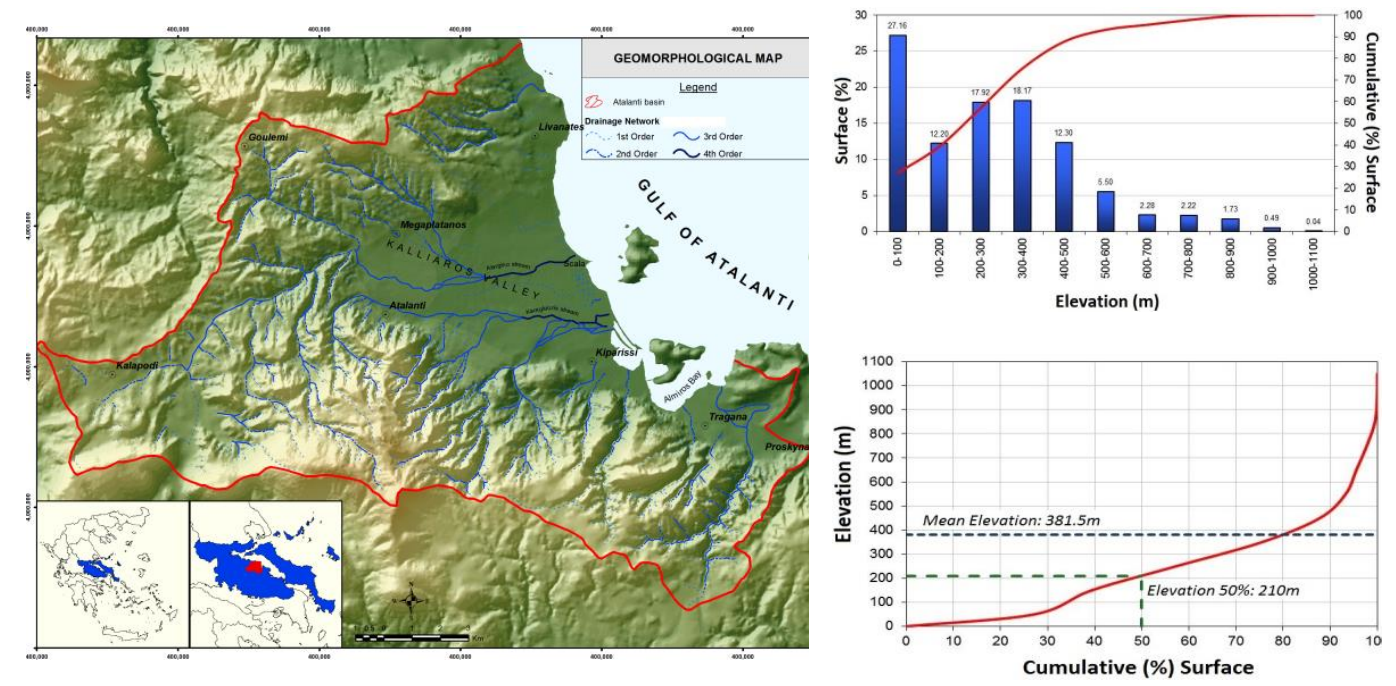

Figure 1 - (left) Geomorphological map and (right) elevation curve vs cumulative surface with mean elevation and elevation $50 \%$ of Atalanti basin.

Atalanti basin has a diverged drainage network (streams, rivers), which has length of several kilometers, converging to the east where it discharges into the Mediterranean. The drainage network within the alluvial basin is regarded dense due to semi-permeable formations while in the rocky areas the intensive and active tectonics has formed a significantly sparse hydrographic network. The southern mountainous part of the above area includes streams with very steep slopes and deep river bed, especially in the parts within carbonate formations. A very important factor in the geomorphological process is the intensive tectonic strain of rocks causing an extensive surface discontinuity, through which the erosion and weathering process is initiated (Palivos, 2001).

\subsection{Geological - Hydrogeological Settings - Tectonics}

The study area belongs to the Subpelagonian geotectonic zone with post alpine deposits coming from the surrounding mountain range rocks (Maratos, 1965). The basin consists of the following formations (Figure 2): (a) Paleozoic formations consisting of shales, sandstones and conglomerates, (b) Triassic and Jurassic dolomites, limestones and ophiolitic rocks (diabases, peridotites,), (c) Creataceous limestones and flysch, $(\boldsymbol{d})$ Neogene sediments deposited after the closed basin formation consisting of marls, calcareous marls, marly limestones, clays, sandy loams, lignite and conglomerates and (e) Quaternary formations deposited at the lower parts of the basin with materials derived from weathering of all previous formations, which come across at higher topographic positions (Angelidis, 1991; Andronopoulos, 1994; Degardin, 1972). The main feature of the geological regime during Miocene is the large-scale faults in Atalanti basin which have created many faulting zones with directions towards West-Northwest and North-Northeast (Karastathis et al., 2007; Kranis, 1999; Memou, 1986; Rondogianni et al., 1986; Sideris, 1986; Stiros et al., 1985).

From the hydrogeological point of view (Figure 3), the study area consists of two main groups of rocks; the first group involves granular formations in which the hydraulic conductivity is based on the primary porosity (pores between the grains), the second group is composed of hard rocks such as limestones and igneous rocks, the hydraulic conductivity of which depends on fractures, fissures, cracks, conduits and other discontinuities. Aquifers of lower storage capacity are developed in the Quaternary - 
Neogene formations and igneous rocks with lateral communication between aquifers in carbonate rocks and the Neogene - Quaternary deposits, forming unconfined and semi-confined aquifers. On the other hand, the confined aquifers are developed within Neogene formations.

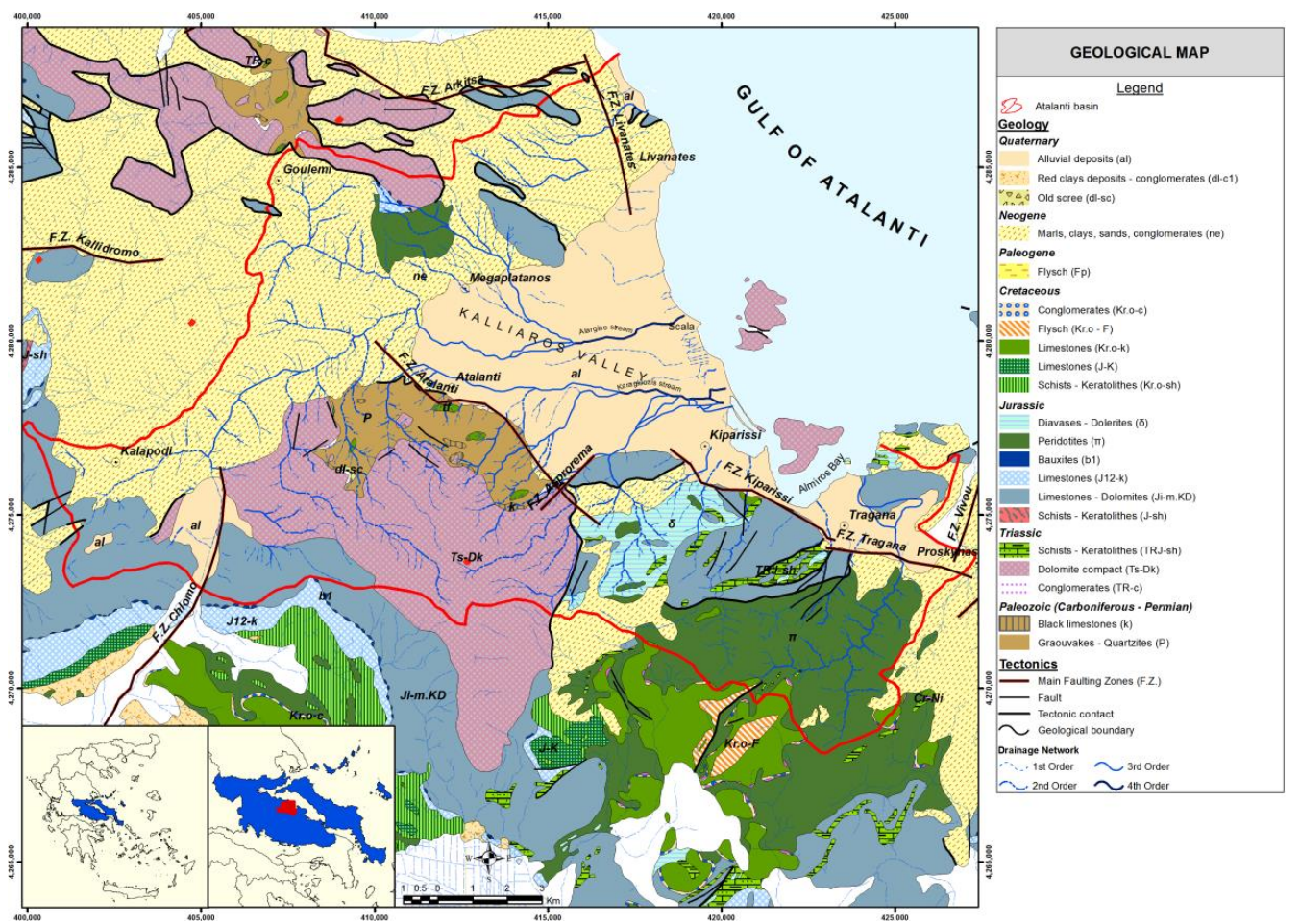

Figure 2 - Regional geological map of the study area's basin (Maratos et al., 1965).

The alluvial deposits due to their heterogeneity may be considered unconfined or semi-confined aquifers (Tsioumas et al., 2011). Finally, groundwater flows are mainly from West towards East (Gulf of Atalanti).

\section{Applied Methodology and Materials}

The contamination of groundwater resources due to sea water intrusion, has dramatically increased during the last decades as a result of aquifer's over-exploitation. Therefore, it is of ample importance to monitor the saltwater/freshwater interface level and control groundwater extraction in coastal aquifers to avoid further quality deterioration. The methodology applied in this study consists of vulnerability assessment to groundwater contamination in Atalanti coastal aquifer through GALDIT method, based on six parameters (Figure 4). Each of GALDIT parameters is calculated and evaluated with the aim of determining the relative role of each parameter. For each GALDIT index, a thematic map is generated using related weight and importance rating.

Chachadi et al. (2001) has proposed a method for coastal aquifer vulnerability mapping including a numerical ranking system to assess seawater intrusion extent. The most important factors influencing seawater intrusion based on the aquifer's intrinsic characteristics are identified as follows: (i) Groundwater occurrence (aquifer type; unconfined, confined and semi confined), (ii) Aquifer hydraulic conductivity, (iii) Height of groundwater level of above sea level, (iv) Distance from the shore (distance inland perpendicular from shoreline), (v) Impact of existing status of seawater intrusion in the area and (vi) Thickness of the aquifer being mapped. Each factor has been evaluated with respect to the others in order to determine the relative importance of each one by 
assigning a relative weight depending on local field conditions. These factors, in combination, are determined to include the basic requirements needed to assess the general seawater intrusion through the spatial distribution of Revelle coefficient, which is calculated for all monitoring wells and spatially mapped using the kriging geostatistical interpolation technique with the aid of GIS generating the raster graphical output for each parameter. Computing the individual indicator scores, summing them and dividing by the total weight the following expression gives the GALDIT Index (Chachadi et al., 2001; Gangadharan et al., 2015; Ferreira et al., 2005; Moghaddam et al., 2015; Najib et al., 2012; Pedreira et al., 2014; Recinos et al., 2014; Savariya et al., 2014; Selmi, 2013).

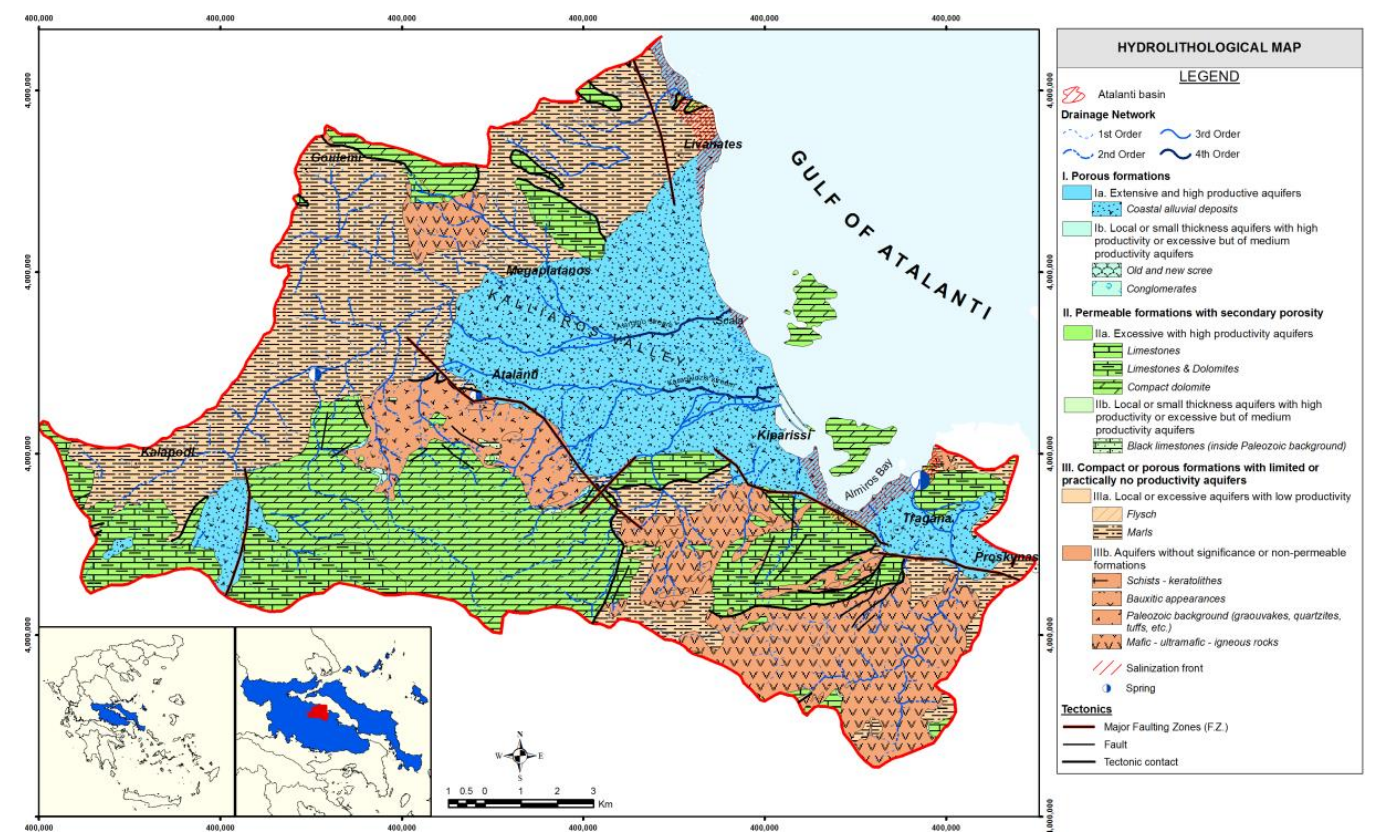

Figure 3 - Hydrolithological map of the study area's basin.

Equation 1 - GALDIT index

$$
\begin{aligned}
& G I=\sum_{i=1}^{6} w_{i} r_{i} / \sum_{i=1}^{6} w_{i}=\left(G_{w} G_{r}+A_{w} A_{r}+L_{w} L_{r}+D_{w} D_{r}+I_{w} I_{r}+T_{w} T\right) / \sum_{i=1}^{6} w_{i} \\
& G I=\left(1 \cdot G_{r}+3 \cdot A_{r}+4 \cdot L_{r}+4 \cdot D_{r}+1 \cdot I_{r}+2 \cdot T\right) / 15
\end{aligned}
$$

where, $w_{i}$ is the weight and $r_{i}$ is the rating of the $i^{\text {th }}$ parameter.

The minimum GALDIT index is obtained by considering the minimum importance ratings of the indicators. The attributed weight for each indicator represents the importance of this indicator respect to the other indicators to assess the seawater intrusion. The minimum and maximum GALDIT index varies between 2.5 and 10 with the highest value indicating a greater vulnerability to the seawater intrusion.

The groundwater samples for $\mathrm{HCO}_{3}{ }^{-}, \mathrm{CO}_{3}{ }^{-2}$ and $\mathrm{Cl}^{-}$analyses, were collected from several groundw ater boreholes evenly distributed within the granular aquifer on 3-month basis between October 20 14 and July 2015. Additionally, the chemical analyses of the same monitoring wells have been take $\mathrm{n}$ into consideration held during the period 2004 - 2008. The concentration ions are estimated in th e accredited and certified Water Analysis Laboratory of the Institute of Geology and Mineral Expl oration (IGME). Also, groundwater levels were measured during the same period in the above mon itoring wells. 


\section{Results and Discussion}

In the following sections, each GALDIT parameter is estimated and spatially mapped (raster form) to show its significance compared to the final vulnerability assessment map against salinization ( $\mathrm{Fi}$ gure 4). The aquifer's type, the hydraulic conductivity, the distance from the shore as well as the aquifer's thickness can be considered as static (steady) long-term parameters while the salinization status and the hydraulic head are dynamic and transient.

\subsection{Model Parameters}

Groundwater occurrence: In unconfined aquifers, the natural condition of the bottom layer has a signi ficant influence on the mixing interface of saltwater and freshwater. Confined aquifers are however, more sensitive because of higher depression levels of water table during well water pumping. Within Atalanti basin the granular aquifer is considered unconfined (coarse materials prevail), that is, ranking equals to 7.5 and given that the parameter weight is 1 , the final value is 7.5 .

Table 1 - GALDIT model parameters showing their ranks (Chachadi et al., 2001, with modifications).

\begin{tabular}{|c|c|c|c|c|c|}
\hline \multicolumn{2}{|c|}{$\begin{array}{c}\text { Groundwater Occurrenc } \\
\text { e }\end{array}$} & \multicolumn{2}{|c|}{$\begin{array}{c}\text { Aquifer Hydraulic C } \\
\text { onductivity (m/day) }\end{array}$} & \multicolumn{2}{|c|}{$\begin{array}{c}\text { Height (m) of Groundwate } \\
\text { r Level (a.s.l.) }\end{array}$} \\
\hline Aquifer Type & Ranking & Range & Ranking & Range & Ranking \\
\hline Confined & 10 & $>80$ & 10 & $<0$ & 10 \\
\hline Unconfined & 7.5 & $60-80$ & 9 & $0-0.5$ & 9 \\
\hline Semi-confined & 5 & $40-60$ & 8 & $0.5-5$ & 8 \\
\hline \multirow[t]{7}{*}{ Bounded } & 2.5 & $30-40$ & 7 & $5-25$ & 7 \\
\hline & & $20-30$ & 6 & $25-45$ & 6 \\
\hline & & $15-20$ & 5 & $45-65$ & 5 \\
\hline & & $10-15$ & 4 & $65-85$ & 4 \\
\hline & & $7.5-10$ & 3 & $85-105$ & 3 \\
\hline & & $5-7.5$ & 2 & $105-125$ & 2 \\
\hline & & $<5$ & 1 & $>125$ & 1 \\
\hline \multicolumn{2}{|c|}{$\begin{array}{l}\text { Distance from the shore ( } \\
\text { m) }\end{array}$} & \multicolumn{2}{|c|}{$\begin{array}{c}\text { Impact of Existing St } \\
\text { atus of Seawater Intr } \\
\text { usion (Revelle) }\end{array}$} & \multicolumn{2}{|c|}{$\begin{array}{c}\text { Thickness of the Aquifer ( } \\
\text { m) }\end{array}$} \\
\hline Range & Ranking & Range & Ranking & Range & Ranking \\
\hline$<100$ & 10 & $>2.0$ & 10 & $>100$ & 10 \\
\hline $100-200$ & 9 & $1.75-2$ & 9 & $60-100$ & 9 \\
\hline $200-300$ & 8 & $1.50-1.75$ & 8 & $30-60$ & 8 \\
\hline $300-400$ & 7 & $1.25-1.50$ & 7 & $20-30$ & 7 \\
\hline $400-600$ & 6 & $1.00-1.25$ & 6 & $15-20$ & 6 \\
\hline $600-800$ & 5 & $0.90-1.00$ & 5 & $12.5-15$ & 5 \\
\hline $800-1000$ & 4 & $0.70-0.90$ & 4 & $10-12.5$ & 4 \\
\hline $1000-1500$ & 3 & $0.50-0.70$ & 3 & $7.5-10$ & 3 \\
\hline $1500-2000$ & 2 & $0.30-0.50$ & 2 & $5-7.5$ & 2 \\
\hline$>2000$ & 1 & $<0.30$ & 1 & $<5$ & 1 \\
\hline
\end{tabular}

Aquifer hydraulic conductivity: The extent of seawater encroachment into the aquifer highly depen ds on the aquifer's hydraulic parameters. Hydraulic conductivity has an important role in aquifer re charge since high values of hydraulic conductivity (in $\mathrm{m} /$ day) associated with wider depression con es during well pumping, result in more significant saltwater intrusion and thus higher vulnerability to contamination. Due to lack of pumping tests, the hydraulic parameters of the study aquifer were derived from geophysical investigations within the area (Memou, 1986). 
Depth to groundwater Level: Groundwater level is one of the most important parameters in evaluating the aquifer's vulnerability to contamination. Specifically for the unconfined aquifers, the deeper groundwater table, the more vulnerable it is to become saline while positive hydraulic head pushes the seawater wedge towards the sea. In the current study piezometric curves are drawn according to the mean groundwater level from 88 wells.

Distance from the shore: The further away from the shore, the less vulnerable the aquifer becomes to saltwater contamination. The parameter's impact is ranked based on the region's topographical map per 100m distance (buffer zones) from the coastline.

Impact of existing status of seawater intrusion: Groundwater overexploitation has led to saltwater movement towards the mainland and thus, increased TDS concentrations If there is no human interference the natural conditions would have established a balanced hydraulic gradient and the saltwater/freshwater interface would be stable with minor changes. Revelle recommended the ratio of $[\mathrm{Cl}-] /([\mathrm{HCO} 3-]+[\mathrm{CO} 3-2])$ as a criterion to identify the extent of seawater intrusion into coastal aquifers. Revelle index is currently used based on the value of ions concentration from 85 wells during the period 2014 - 2015.
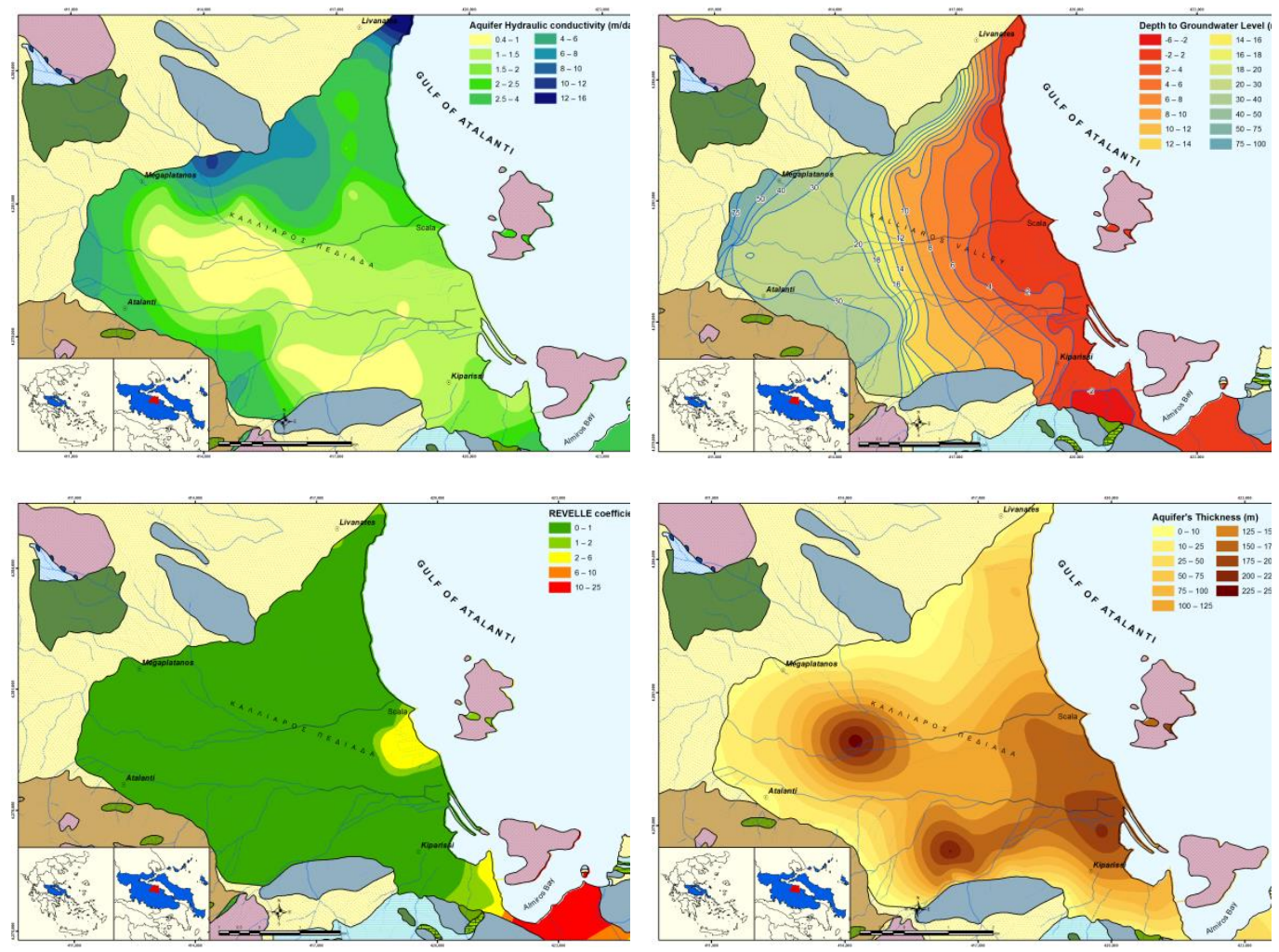

Figure 4 - GALDIT model parameters raster maps.

Thickness of the aquifer: This parameter is used to estimate the amount of seawater intrusion into coastal aquifers. Increased thickness of the saturated zone results in lower saltwater levels and thus, decreased vulnerability. The granular aquifer's thickness as well as the impermeable formation's depth (marls) is estimated through previous geophysical studies within the area (Memou, 1986).

Based on Table 2, GALDIT vulnerability map depicts the different degrees of the aquifer's sensitivity to seawater intrusion along Atalanti coastal aquifer. The map divides the alluvial deposits into five vulnerability zones. The orange and dark yellow zone represents a high - very high vulnerability level in the eastern and southern part of the aquifer, corresponding to the $21.9 \%$ of the 
total area (Tragana, Scala and Livanates). Yellow color indicates the distribution of moderately vulnerable zones, which cover $67.2 \%$ of the total area covering the center of the alluvial basin. This is due to the lower groundwater levels and the relatively higher hydraulic con-ductivity in that zone. Finally, the green colored zones indicate a lower vulnerability, corresponding to the $10.9 \%$ of the total area (Figure 5).

Table 2 - GALDIT index ranges spatial distribution.

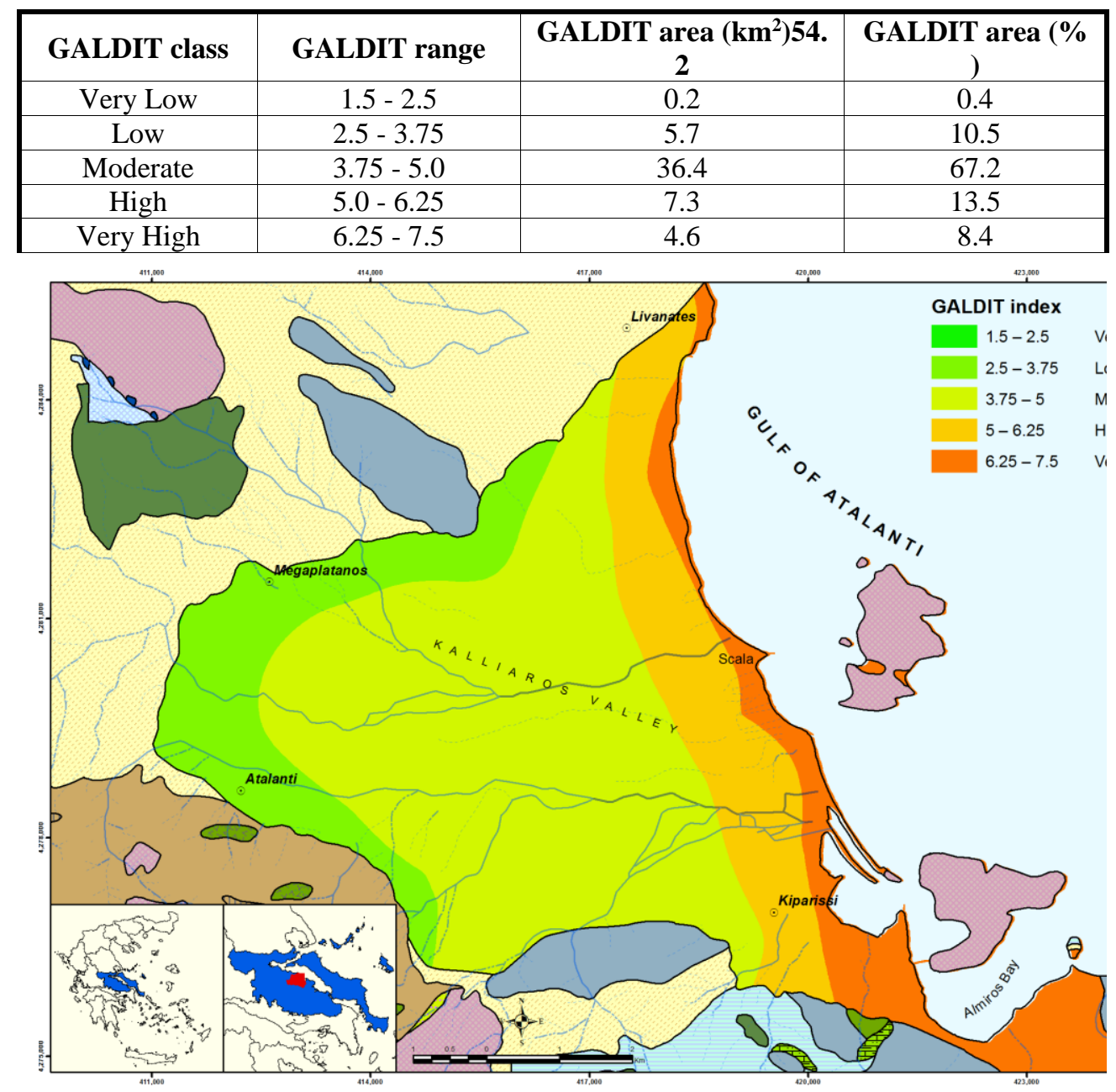

Figure 5 - GALDIT vulnerability assessment map against seawater intrusion.

\subsection{Validation}

By applying a simple linear regression analysis between T.D.S. concentration and E.C. values vs GALDIT index, it is proved that there is a quite satisfactory correlation $\left(r^{2}=0.76, r^{2}=0.73\right.$ respectively). Consequently, the applied index is well validated by the field measurements and chemical analyses. Besides, the seawater intrusion phenomenon is considered to be important and alarming in that case in which both well over-exploitation and over pumping continue without any control. That would result in further groundwater salinization (towards inland), therefore groundwater would become inappropriate even for resistant cultivations. To that direction, the well drilling should be limited and restrictive pumping limits per crop from current wells should be set otherwise the seawater intrusion phenomenon will become irreversible 


\section{Conclusions}

The aquifer vulnerability mapping of Atalanti coastal region due to seawater intrusion, through GALDIT method, has been successfully used to assess the extent of aquifer vulnerability to salinization. The generated map shows different vulnerability levels for different part of Atalanti aquifer regarding seawater intrusion. The application of GALDIT method to the coastal aquifer made it possible to evaluate the impact of the salinization characterized by a low vulnerability index in uplands and by high vulnerability in the low-lands along the shoreline. According to the applied method the aquifer is highly vulnerable up to $1.8 \mathrm{~km}$ towards the mainland for almost the entire coastal part. The distribution of low-very low, moderate and high-very high vulnerability class are $10.9 \%, 67.2 \%$ and $21.9 \%$ of the total study area, respectively. Validation is performed based on the relatively high linear regression between the results obtained from the vulnerability index and T.D.S.-E.C. values. The seawater vulnerability map derived using GALDIT method indicates that the coastal granular aquifer shows moderate to high susceptibility to seawater intrusion. Finally, from all the above evidence, GALDIT method can be considered as quite effective for assessing groundwater vulnerability to seawater intrusion. The resulted vulnerability map is a useful management tool that can be used to control and manage seawater intrusion in different types of coastal aquifers, illustrating the parts where the aquifer is more vulnerable and should be monitored more intensively.

\section{Acknowledgements}

The authors wish to express their thanks to the scientific and technical stuff of the Institute of Geology and Mineral Exploration for the help offered to all phases of the groundwater field sampling work as well as to the groundwater samples' chemical analysis.

\section{References}

Angelidis, Ch., 1991. Technical-geological research in Atalanti regional area, PhD, School of Mining and Metallurgical Engineering, NTUA, Athens.

Andronopoulos, B., 1994. Geological - tectonic study of Atalanti region, IGME, Athens.

Chachadi, G. and Lobo-Ferreira, P., 2001. Sea water intrusion vulnerability mapping of aquifers using GALDIT method, Proc. Workshop on Modelling in Hydrogeology, Anna University, Chennai, 143-156.

Degardin, J., 1972. Etude geologique de la region d' Atalanti (Locride, Grece continentale), Ann. Soc. Geol. Nord., XCII (4), 213-220.

Gangadharan, R. and Rekha, N., 2015. GIS based GALDIT-AHP Method for Assess the Impact of Shrimp Farms in Coastal Watershed of Tamil Nadu, INDIA, International Journal of Engineering Research \& Technology (IJERT), 4(2).

Karastathis, V., Ganas, A., Makris, J., Papoulia, J., Dafnis, P., Gerolymatou, E. and Drakatos, G., 2 007. The application of shallow seismic techniques in the study of active faults: The Atalant i normal fault, central Greece, Journal of Applied Geophysics, 62, 215-233.

Kranis, Ch., 1999. Neotectonic activity of Central - Eastern Greece faulting zones (Locride), PhD, School of Sciences, Department of Geology, National and Kapodistrian University of Athens, $233 \mathrm{pp}$.

Lobo Ferreira, P., Chachadi, G., Diamantino, C. and Henriques, J., 2005. Assessing aquifer vulnerability to seawater intrusion using GALDIT method: GALDIT Indicators Description. Proceedings of the 4th InterCeltic Colloquium on Hydrology and Management of Water "Water in Celtic Countries: Quantity, Quality and Climate Variability", 1-9.

Maratos, G., Rigopoulos, K. and Athanasiou, A., 1965. Geological map of Atalanti sheet, scale 1:50.000, Institute of Subsurface Geological Research.

Memou, T., 1986. Geophysical research of Atalanti region, IGME, Athens. 
Moghaddam, H., Jafari F. and Javadi S., 2015. Evaluation Vulnerability of coastal aquifer via GALDIT model and comparison with DRASTIC Index using quality parameters, Hydrological Sciences Journal, doi: 10.1080/02626667.2015.1080827.

Najib, S., Grozavu, A., Mehdi, K., Gabriela, I., Guessir, H. and Boutayeb, K., 2012. Application of the Method GALDIT for the Cartography of Groundwaters Vulnerability: Aquifer of Chaouia Coast (Morocco), Scientific Annals of Alexandru Ioan Cuza, University of Iasi, Geografie, LVIII.

Palivos, N., 2001. Geomorphological study of Atalanti area of Fthiotida prefecture, PhD, School of Sciences, Department of Geology, Athens.

Pavlidou, E., 2010. Impacts of human activities on groundwater quality in Atalanti region, MSc Thesis, Hellenic Open University.

Pedreira, R., Kallioras, A., Pliakas, F., Gkiougkis, I. and Schuth, C., 2014. Groundwater vulnerability assessment of a coastal aquifer system at River Nestos eastern Delta, Greece, Environmental Earth Science, 123, doi: 10.1007/s12665-014-3864-7.

Recinos, N., Kallioras, A., Pliakas, F. and Schuth, C., 2014. Application of GALDIT index to assess the intrinsic vulnerability to seawater intrusion of coastal granular aquifers. Environmental Earth Sciences, 73(3), 1017-1032.

Rondogianni, Th. and Papadakis, J., 1986. Geological - seismotectonic conditions of Atalanti region. IGME, 5 pp.

Savariya, P. and Bhatt, N., 2014. Assessing Groundwater Vulnerability to Seawater Intrusion in Morbi-Maliya Using GALDIT Method, International Journal for Scientific Research \& Development, 2(4).

Selmi, A., 2013. Water Management and Modelling of a Coastal Aquifer - Case Study (Gaza strip), $\mathrm{PhD}$ in Earth Sciences, University of Milan Bicocca, Faculty of Mathematics, Physics and Natural Sciences, Department of Earth and Environmental Sciences.

Sideris, Ch., 1986. Contribution of the geodynamic evolution of Eastern Greece during Permian Triassic, PhD, School of Sciences, Department of Geology, National and Kapodistrian University of Athens, $214 \mathrm{pp}$.

Stiros, S. and Rondogianni, Th., 1985. Recent vertical movements across the Atalandi fault zone (central Greece), Pure Appl. Geophys., 123, 837-848.

Tsioumas, V., Zorapas, V., Pavlidou, E., Lappas, I. and Voudouris, K., 2011. Groundwater contamination by nitrates and seawater intrusion in Atalanti basin (Fthiotida, Greece), Proceedings of the 9th International Congress of Greek Hydrogeological Society. 